\title{
Phenotypic plasticity of the basidiomata of Thelephora sp. (Thelephoraceae) in tropical forest habitats
}

\author{
Itzel Ramírez-López ${ }^{1 *}$, Margarita Villegas Ríos ${ }^{1} \&$ Zenón Cano-Santana ${ }^{2}$ \\ 1. Laboratorios de Micología, Edificio A 3er piso, Facultad de Ciencias, Universidad Nacional Autónoma de México, \\ Ciudad Universitaria, Delegación Coyoacán, D.F., México, C.P. 04510; itzel_ramirez_lopez@yahoo.com.mx, \\ mvr@hp.fciencias.unam.mx \\ 2. Grupo de Interacciones y Procesos Ecológicos, Edificio B 2do piso, Facultad de Ciencias, Universidad Nacional \\ Autónoma de México, Ciudad Universitaria, Delegación Coyoacán, D.F., México, C.P. 04510; \\ zcs@ciencias.unam.mx \\ * Corresponding author
}

Received 26-X-2011. C Corrected 06-VII-2012. Accepted 09-VIII-2012.

\begin{abstract}
Phenotypic plasticity in macroscopic fungi has been poorly studied in comparison to plants or animals and only general aspects of these changes have been described. In this work, the phenotypic variation in the basidiomata of Thelephora sp. (Thelephoraceae) was examined, as well as some aspects of its ecology and habitat, using 24 specimens collected in the tropical forests of the Chamela Biological Station, Jalisco, Mexico. Our observations showed that this taxon has clavarioid basidiomata that can become resupinate during development and growth if they are in contact with rocks, litter or live plants, establishing in the latter only an epiphytic relationship. This tropical species may form groups of up to 139 basidiomata over an area of $32.2 \mathrm{~m}^{2}$, and in both types of vegetation (tropical sub-evergreen and deciduous forest) were primarily located on steep $\left(>20^{\circ}\right)$ South-facing slopes. It is found under closed canopy in both tropical forests, but its presence in sub-evergreen forests is greater than expected. Rev. Biol. Trop. 61 (1): 343-350. Epub 2013 March 01.
\end{abstract}

Key words: Thelephora, basidiome, phenotypic plasticity, tropical forest.

The formation of basidiomata constitutes part of the sexual process of Agaricomycotina, and serves the purpose of producing and dispersing spores. The development of these structures is influenced by the interaction of both intrinsic (genetic and physiological) and extrinsic (environmental) factors (Moore-Landecker 1996, Moore et al. 2008, 2011). It has been noted that the development of basidiomata of Coprinus spp. Panus fragilis, Morchella sp., Pleurotus ostreatus and Thyphula ishikariensis is affected by environmental factors including the availability of nutrients, temperature, humidity, light, and $\mathrm{pH}$ (Morimoto \& Oda 1973, Bujakiewicz 1992, Kost 1992, Boulianne et al. 2000, Straatsma et al. 2001, Salerni et al. 2002, Kawakami et al. 2004, Singh et al. 2004,
Suárez-Duque 2004, Gibertoni et al. 2007, Pilz et al. 2007, Lodge et al. 2008). The shape of the basidiome, however, is genetically determined (Cooke \& Whipps 1993, Griffin 1994, Moore 1998, Schmidt 2006, Moore et al. 2008), with several basic shapes (corticoid, cyphelloid, clavarioid, dimidiate, effused-reflex and pileatestipitate), being commonly recognized among different taxa (Corner 1968, Clémençon 1997). Phenotypic plasticity is a mechanism that allows organisms to deal with environmental heterogeneity (Valladares et al. 2007). Macroscopic fungi are no exception, having the ability to modify their basidiome morphology in response to varying environmental conditions (McGonigle 1995, Mswaka \& Magan 1999). Numerous studies, such as Gottlieb \& Wright 
(1999), have reported phenotypic plasticity in both micro- and macro-morphological characters of South American species of Ganoderma, but without considering their causal factors. In other cases, such as Pleurotus sajor-caju, phenotypic variability in the number of concentric lines of the pileus, deformation of the primordia, and reduced growth in response to environmental conditions, particularly temperature and $\mathrm{pH}$, has been observed (Kashangura et al. 2006). Similarly, Peabody et al. (2003) suggested that some factors are implicated in determining the genetic variability of the number, size, and shape of the basidiomata of Armillaria gallica. In the case of clavarioid fungi, morphological variation in response to changes in nutrients, $\mathrm{pH}$, and light has been seen in vitro in Artomyces pyxidatus and Pterula echo (Dodd 1972, McLaughlin \& McLaughlin 1972, 1980, James \& McLaughlin 1988), but such variation has not been clearly documented in natural conditions.

Worldwide, the genus Thelephora includes at least 50 species (Kirk et al. 2008), some of which are characterized by the ability to form resupinate, clavarioid, or pileate-stipitate basidiomata (Corner 1968, Sánchez-Jácome \& Guzmán-Dávalos 1997). Approximately 28 of these species are found in tropical and subtropical ecosystems, and 10 of them develop clavarioid basidiomata (Corner 1968, Stalpers 1993). One of the notable characters that differentiate species is the macromorphology of the basidiome, but Cunningham (1957) mentioned that variations of form may complicate the characterization of taxa. There are also taxa such as T. atra Weinm., T. dentosa Berk. \& M.A. Curtis, T. investiens Corner, T. japonica Yasuda, T. penicillata (Pers.) Fr., T. pseudoterrestris Corner and T. terrestris Ehrh. which incrust on inert or living substrates independently of the form of the basidiome (Cunningham 1957, Watling 1996, Corner 1968). Cunningham (1957) did not consider any of the species to be parasitic, but Corner (1968) referred to some species as weakly parasitic because of their propensity to kill plant substrates due to interference with photosynthetic activity.
The environmental conditions and phenotypic plasticity of the basidiomata of Thelepho$r a$ have not been well studied. The objectives of this study were to describe the natural phenotypic variation of the basidiomata of Thelephora sp. and to examine aspects of its ecology, spatial distribution, and habitat.

\section{MATERIALS AND METHODS}

The study was carried out in the Chamela Biological Station (CBS), located in the Pacific coast of the Mexican state of Jalisco $\left(19^{\circ} 30^{\prime} \mathrm{N}-105^{\circ} 03^{\prime} \mathrm{W}\right.$; Bullock 1988). Vegetation is predominantly deciduous tropical forest, with a smaller area covered by sub-evergreen tropical forest (Lott \& Atkinson 2002). The slopes vary between $21-34^{\circ}$, but the elevation does not surpass 580m (Martínez-Yrizar \& Sarukhán 1993). Soils are poorly developed young entiosols (or haplic phaeozem) with little organic material and a $\mathrm{pH}$ between 6-7 (Solís 1993). Climate is warm sub-humid $\left(\mathrm{Aw}_{0} \mathrm{i}\right)$, with a marked seasonality (GarcíaOliva et al. 1995, 2002).

Specimens $(n=24)$ of Thelephora were collected during the rainy seasons of 20052008. Ecological data were also collected, including vegetation type, substrate, canopy cover, orientation and slope, abundance and distribution area of the basidiomata, and the growth form of the basidiome. Habitat orientation and slope were measured with an azimuth compass and a clinometer.

Determination of the specimens was made following normal mycological methods, considering both macro -and microscopic- characters and including reactions with potassium hydroxide and observation of spores using scanning electron microscopy. A number of references were consulted during determination, including Corner (1968, 1976), Ellis \& Ellis (1990), Marmolejo et al. (1981), Stalpers (1993), and Sánchez-Jacome \& Guzmán Dávalos (1997). Evaluation of the relationship of the basidiomata with living substrates was made via observation of rehydrated specimens under a stereoscopic microscope. 
A chi-squared test was used to determine if basidiomata were distributed randomly with respect to vegetation type, slope, and orientation. Expected values for the chi-square test were estimated from a sampling of 355 points made every $10 \mathrm{~m}$ along the trails used to find basidiomata of the clavarioid fungi.

\section{RESULTS}

Basidiomata were found to develop in sites beneath a closed canopy, regardless of the level of perturbation at ground level. The relative abundance of basidiomata was $27.9 \%$ with respect to other clavarioid fungi found at CBS. The growth form observed was solitary to somewhat gregarious, with between 1-139 basidiomata observed, occupying an area between $0.07-32.2 \mathrm{~m}^{2}$ (Fig. 1A).

The macromorphology of the 24 specimens studied was variable, with 11 of the samples revealing a completely clavarioid form and the rest partially resupinate or a more branched form caused by growth around a physical obstruction; both forms were seen even within a single collection (Figs. 1B-E).
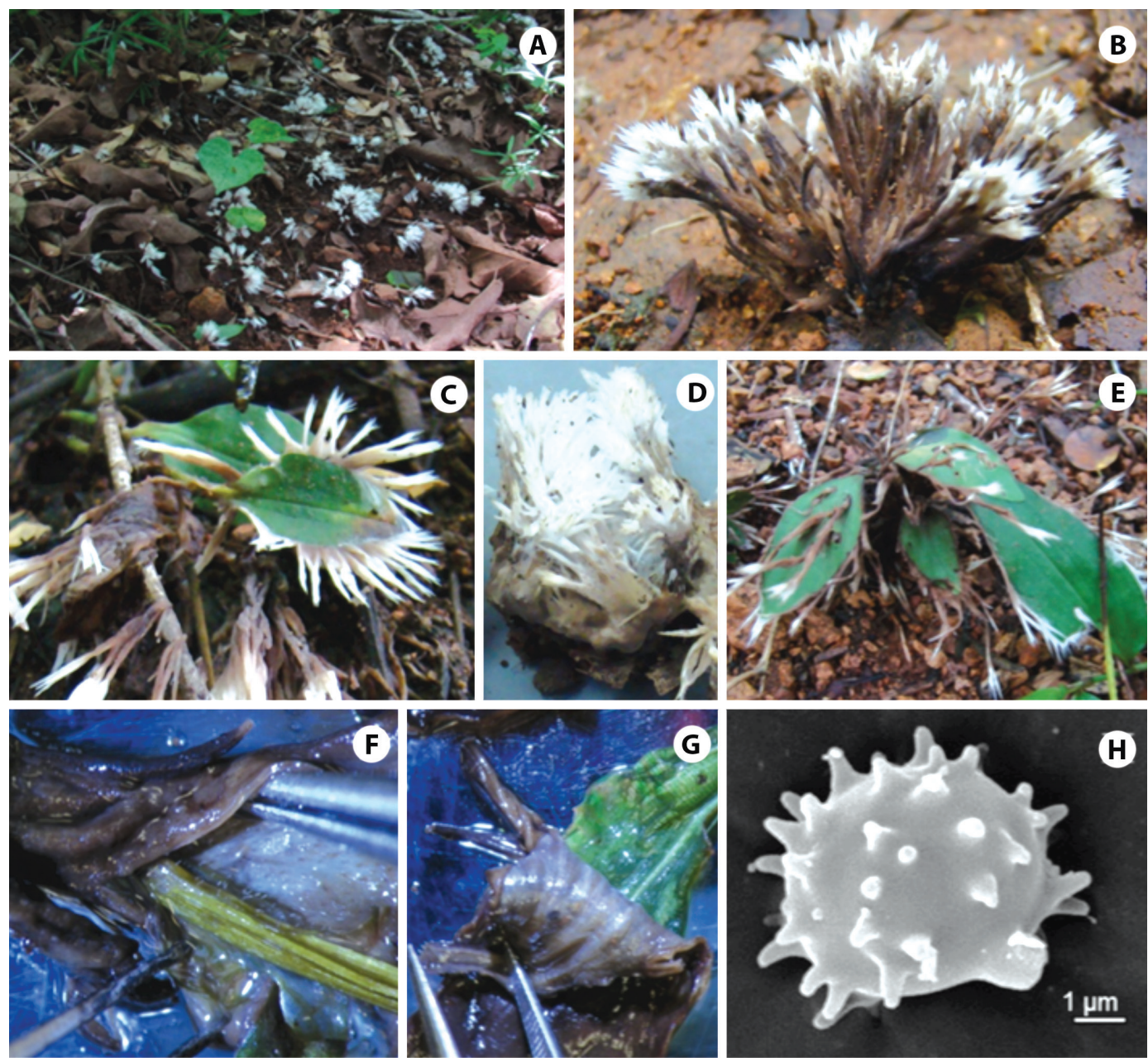

Fig. 1. Thelephora sp. (A) little gregarious growth of basidiomata on the ground (B) clavarioid basidiome well defined. (C) resupinated basidiome that return to the clavarioid form. (D) resupinated basidiome on a piece of rock. (E) leaf lamina crossed by basidiome. (F-G) epiphytic relationship on living plants. (H) spore by scanning electron microscopy. 
Basidiomata were observed growing on plants of the families Convolvulaceae, Sapindaceae, Commelinaceae, Acanthaceae, Asteraceae, Sterculiaceae, Rhamnaceae, Poaceae and Fabaceae. Basidiomata indiscriminately surrounded both stems and leaves (Figs. 1F-G), and occasionally perforated tissue, growing through leaf lamina without causing mortality (Fig. 1E). The fungi were evidently growing as epiphytes, as no penetration of plant tissue was observed, and fungi were easily separated from their substrate (Figs. 1F-G), even in preserved specimens.

The length of the basidiomata varied between $8-145 \mathrm{~mm}$, with color ranging from light or reddish brown to dark-violet brown (6D2-16F8; Kornerup \& Wanscher 1978) on the base and intermediate part, whereas apices were grey or light yellow to white (2A2-16A1; Kornerup \& Wanscher 1978). The hymenium was always smooth regardless of the form of the basidiome.

All specimens showed similar micromorphology and reaction to potassium hydroxide in all tissues. The similarity of size, shape, ornamentation, and type of hylar appendix of the spores observed under scanning electron microscopy confirmed the similarity of all specimens (Fig. 1H). These combined characters and molecular data allowed identification of all the specimens studied as belonging to a new species of Thelephora.
Basidiomata were observed after accumulative precipitation surpassed $400 \mathrm{~mm}$. Although specimens were found on slopes of varying orientation and inclination $\left(9-41^{\circ}\right)$, South-facing slopes were significantly more common $\left(\chi^{2}=4.9\right.$, d.f. $=1, p<0.05$; Fig. 2$)$ as were slopes steeper than $20^{\circ}\left(\chi^{2}=72.7\right.$, d.f. $=1$, $\mathrm{p}<0.001$; Fig. 3). Finally, specimens of $T$. sp. were found more commonly in the sub-evergreen tropical forest than expected by chance $\left(\chi^{2}=13.5\right.$, d.f. $=1, p<0.001$; Fig. 4).

\section{DISCUSSION}

Phenotypic plasticity has been widely studied in plants (Palacio-López \& Rodríguez-López 2007, Valladares et al. 2007) but poorly studied in fungi. This work demonstrates that the unusual growth form found in some basidiomata of $T$. sp. is a characteristic that allows it to fully develop in spite of inert or organic barriers that it may encounter during development.

The observation of basidiomata that adhere to living plant matter has been previously reported for a number of temperate species with stereoid basidiomata such as Thelephora terrestris and T. griseozonata (Cunningham 1957, Corner 1968, Watling 1996). This process has traditionally been described as incrustation, however, studies demonstrating the type

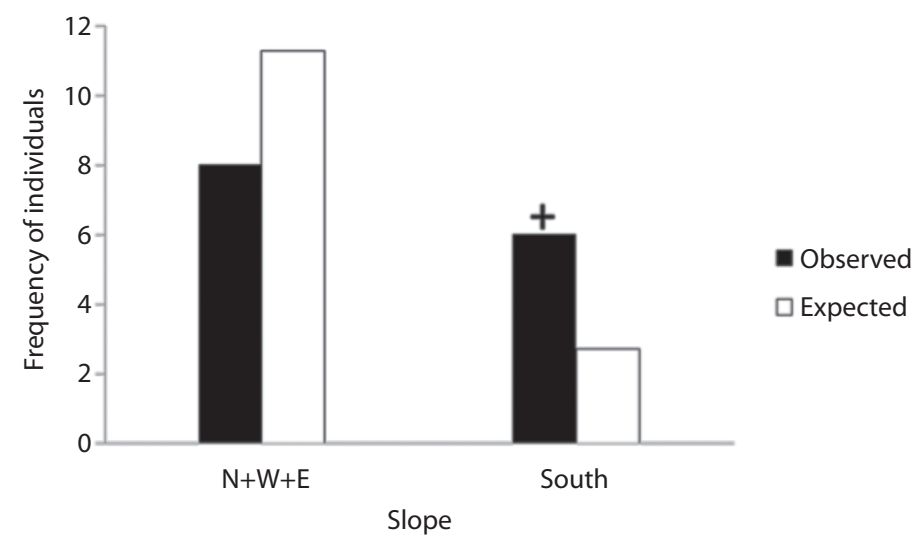

Fig. 2. Frequency of individuals observed and expected of Thelephora sp., grouped data from the Northern slopes (N), West (W) and Eastern (E) with respect to the South. 


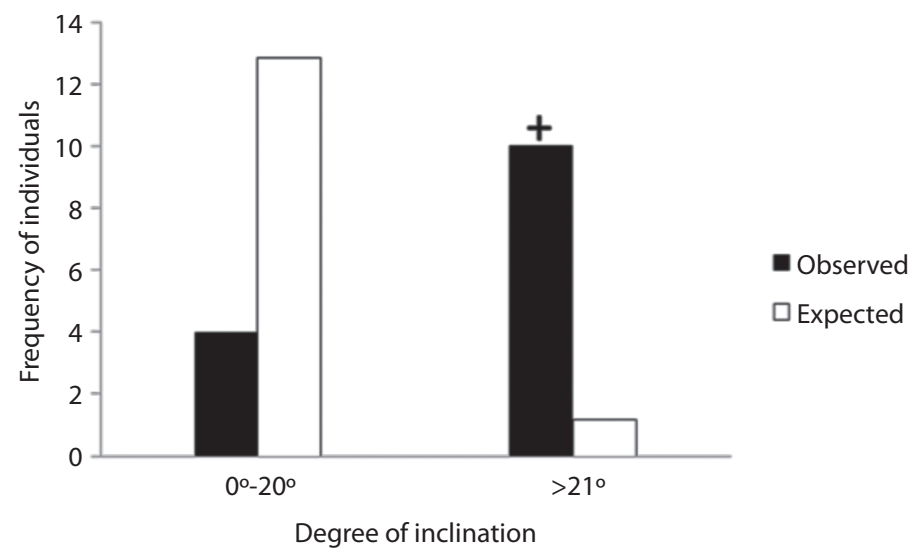

Fig. 3. Frequency of individuals observed and expected of Thelephora sp., grouped data from the inclination of $0^{\circ}-20^{\circ}$ and more than $21^{\circ}$.

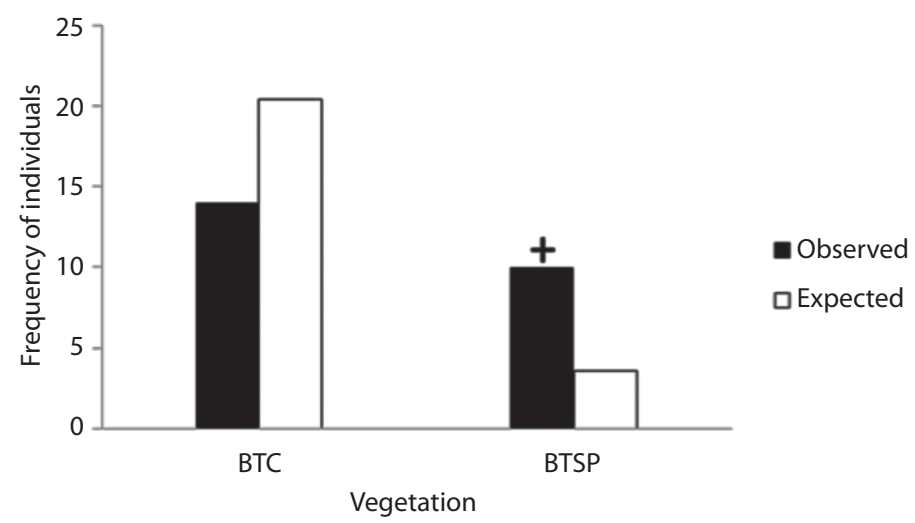

Fig. 4. Frequency of individuals observed and expected of Thelephora sp., over the tropical deciduous forest (BTC) and evergreen tropical forest (BTSP).

of interspecific interaction have been lacking. The current study was able to demonstrate that $T$. sp. maintains an entirely epiphytic relationship with the plants to which it adheres, similar to what was proposed by Cunningham (1957) and referred to by Corner (1968) as weak parasitism. Our data show, moreover, that $T$. sp. does not demonstrate specificity towards particular plant parts or taxa. It is important to note, however, that although the growth form of the basidiomata of $T$. sp. is variable, the difference in growth form is temporary, as the basidiomata regain their clavarioid growth as soon as they have surpassed barriers in their path (Fig. 1C).
The particular behavior of $T$. sp. is relevant from several perspectives: (1) biologically, as it indicates that this organism has the capacity to modify the development of its basidiomata and regain its original form; (2) taxonomically, in the interpretation of the observed variation of form as a differentiating character; and (3) ecologically, as a strategy for the species to complete the development of basidiomata in spite of barriers during development.

Among the diversity of clavarioid fungi present in CBS, the taxon studied here presented the greatest abundance of basidiomata, observable in all four of the sampled rainy 
seasons. Thanks to its leathery consistency, $T$. sp. also lasts for a longer duration than other clavarioid fungi. This abundance suggests the success of the basidiomal growth form of $T$. sp. in these ecosystems that have such marked deciduous seasonality.

Among the extrinsic factors which affect the formation of basidiomata of macroscopic fungi, humidity has been the best studied. A high correlation has been found between humidity and the formation of these structures (Straatsma et al. 2001, Salerni et al. 2002, Miyamoto \& Igarashi 2004, Munguia et al. 2006, Gómez Hernández 2009). Although basidiomata of $T \mathrm{sp}$. were only found during the rainy season, the ecological data presented here indicate that their distribution is not random, but instead influenced by slope, orientation, and vegetation type.

The high frequency of $T$. sp. specimens found on south-facing slopes suggests that light may be an important factor in the formation and maturation of its reproductive structures. The effect is not likely to be direct, however, as specimens were most commonly found under closed canopies where they reach greater length. Laboratory experiments have shown that the range and duration of light exposure plays an important role in the formation of basidiomata of fungi such as Coprinus spp., Typhula ishikariensis and Clavicorona pyxidata (Morimoto \& Oda 1973, James \& McLaughlin 1988, Boulianne et al. 2000, Kawakami et al. 2004).

$T$. sp. was found predominantly on slopes steeper than $20^{\circ}$, perhaps due to factors related to humidity and nutrient requirements. In samples of mycelia across a gradient from $0-25^{\circ}$, Lodge et al. (2008) observed that mycelial coverage was positively correlated with slope, and suggested that the correlation was likely due to improved nutrient uptake on steep slopes with lower humidity but high nutrient availability from runoff.

The data obtained in this study also reveal that basidiomata of $T$. sp. are more frequent than expected in the relatively uncommon sub-evergreen forests of CBS, likely due to canopy coverage. Studies by Lodge \& Cantrell (1995), Suárez-Duque (2004), Gibertoni et al. (2007) and Lodge et al. (2008) have shown a relationship between the extent of canopy coverage and light incidence in tropical zones.

Future studies investigating the roles of conductivity and distribution of nutrients and the structure and type of soils will be necessary for a more detailed understanding of the development and distribution of this species.

\section{ACKNOWLEDGMENTS}

We would like to thank the Chamela Biological Station, of the Institute of Biology of UNAM, for providing the facilities for carrying out this work, to CONACYT for the scholarship provided to the first author (210504) and DGAPA project: PAPITT IN-203009-3 for the financial support. We would also like to thank Juan José Morrone and Iván Castellanos-Vargas provided insightful comments on the preparation of this manuscript, and Silvia Espinoza Matias for her photographic work for SEM.

\section{RESUMEN}

La plasticidad fenotípica en hongos macroscópicos ha sido poco estudiada en comparación con la de plantas o animales y solo se conocen aspectos generales de estos cambios. En este trabajo se examinó la variación fenotípica en los basidiomas de una especie de Thelephora sp. (Thelephoraceae), así como algunos aspectos de su ecología y hábitat a partir del estudio de 24 ejemplares recolectados en bosques tropicales de la Estación de Biología de Chamela, Jalisco, México. Nuestras observaciones mostraron que este taxon presenta basidiomas en forma clavarioide, los cuales pueden modificarse a resupinados si en su proceso de desarrollo se interponen obstrucciones físicas como rocas, restos vegetales o plantas vivas, estableciendo en estas últimas solo una relación epifítica. Esta especie llega a formar conjuntos de hasta 139 basidiomas en un área de $32.2 \mathrm{~m}^{2}$; con localización predominante en laderas orientadas hacia el sur, de pendientes mayores a $20^{\circ}$, bajo doseles cerrados y con presencia mucho más significativa de lo esperado en el bosque tropical subperennifolio.

Palabras clave: Thelephora, basidioma, plasticidad fenotípica, bosque tropical. 


\section{REFERENCES}

Boulianne, R.P., Y. Liu, M. Aebi, B.C. Lu \& U. Kües. 2000. Fruiting body development in Coprinus cinereus: regulated expression of two galectins secreted by a non-classical pathway. Microbiology 146 : 1841-1853.

Bujakiewicz, A. 1992. Macrofungi on soil in deciduos forest, p. 49-78. In W. Winterhoff (ed.). Fungi in vegetation science. Kluwer Academic, Dordrecht, Holland.

Bullock, S.H. 1988. Rasgos del ambiente físico y biológico de Chamela, Jalisco, México. Folia Entomol. Mexic. 77: 5-17.

Clémençon, H. 1997. Anatomy of the Hymenomycetes: an introduction to the cytology and plectology of crust fungi, bracket fungi, club fungi, Chanterelles, Agarics and Boletes. F. Flück-Wirth, Teufen, Switzerland.

Cooke, R.C. \& J.M. Whipps. 1993. Ecophysiology of Fungi. Blackwell, Oxford, England.

Corner, E.J.H. 1968. A Monograph of Thelephora (Basidiomycetes). Nova Hedwigia Beih. 27:1-110.

Corner, E.J.H. 1976. Futher notes on Cantharelloid fungi and Thelephora. Nova Hedwigia 27: 325-342.

Cunningham, G.H. 1957. Thelephoraceae of New Zealand (parts XII and XIII). Part XII: The genera Thelephora and Tomentella. Trans. Roy. Soc. N.Z. 84: 479-496.

Dodd, J.L. 1972. The genus Clavicorona. Mycologia 64: 737-773.

Ellis, M.B. \& J.P. Ellis. 1990. Fungi without gills (Hymenomycetes and Gasteromycetes): An identification handbook. Chapman and Hall, Bury St. Edmunds, Suffolk, England.

García-Oliva, F., A. Camou \& J.M. Maass. 2002. El clima de la región central de la costa del Pacífico mexicano, p. 3-10. In F.A. Noguera, J.H. Vega Rivera, A.N. García-Aldrete \& M. Quesada-Avendaño (eds.). Historia Natural de Chamela. Instituto de Biología, Universidad Nacional Autónoma de México, D.F., México.

García-Oliva, F., J.M. Maass \& L. Galicia. 1995. Rainstorm analysis and rainfall erosivity of a Seasonal Tropical Region with a strong cyclonic influence on the Pacific Coast of Mexico. J. Appl. Meteorol. 34: 2491-2498.

Gibertoni, T.B., P.J.P. Santos \& M.A.Q. Cavalcanti. 2007. Ecological aspects of Aphyllophorales in the Atlantic Rain Forest in Northeast Brazil. Fungal Divers. 25: 49-67.

Gottlieb, A.M. \& J.E. Wright. 1999. Taxonomy of Ganoderma from southern South America: subgenus Elfvingia. Mycol. Res. 103: 1289-1298.

Griffin, D.H. 1994. Fungal physiology. Wiley-Liss, New York, USA.
Gómez Hernández, M.A. 2009. Diversidad de macromicetes en relación a estructura, especies arbóreas y microclima del bosque mesófilo de montaña en el centro de Veracruz, México. Tesis de Maestría, Instituto de Ecología, Xalapa, Veracruz, México.

James, S.W. \& D.J. McLaughlin. 1988. The influence of carbohydrate source and concentration and light on fruitbody development in Clavicorona pyxidata. Mycologia 80: 89-98.

Kashangura, C., J.E. Hallsworth \& A.Y. Mswaka. 2006. Phenotypic diversity amongst strains of Pleurotus sajor-caju: implications for cultivation in arid environments. Mycol. Res. 110: 312-317.

Kawakami, A., N. Matsumoto \& S. Naito. 2004. Environmental factors influencing sporocarp formation in Typhula ishikariensis. J. Gen. Plant Pathol. 70: 1-6.

Kirk, P.M., P.F. Cannon, D.W. Minter \& J.A. Stalpers (eds.). 2008. Ainsworth \& Bisby's Dictionary of the Fungi. CABI Europe-UK, Wallingford, England.

Kornerup, A. \& J.H. Wanscher. 1978. Methuen handbook of colour. Methuen, London, England.

Kost, G. 1992. Macrofungi on soil coniferous forest, p. 79-111. In W. Winterhoff (ed.). Fungi in vegetation science. Kluwer Academic, Dordrecht, Holland.

Lodge, D.J., W.H. McDowell, J. Macy, S.K. Ward, R. Leisso, K. Claudio-Campos \& K. Kühnert. 2008. Distribution and role of mat-forming saprobic Basidiomycetes in a Tropical Forest, p. 197-209. In L. Boddy, J.C. Frankland \& P.V. West (eds.). Ecology of Saprotrophic Basidiomycetes. Academic, London, England.

Lodge, D.J. \& S. Cantrell. 1995. Fungal communities in wet tropical forests: variation in time and space. Can. J. Bot. 73: S1391-S1398.

Lott, E.J. \& T.H. Atkinson. 2002. Biodiversidad y fitogeografía de Chamela-Cuixmala, Jalisco, p. 83-97. In F.A. Noguera, J.H. Vega Rivera, A.N. García-Aldrete \& M. Quesada-Avendaño (eds.). Historia Natural de Chamela. Instituto de Biología, Universidad Nacional Autónoma de México, D.F., México.

Marmolejo, J.G., J. Castillo \& G. Guzmán. 1981. Descripción de especies de teleforáceos poco conocidos en México. Bol. Soc. Mex. Mic. 15: 9-66.

Martínez-Yrizar, A. \& J. Sarukhán. 1993. Cambios estacionales del mantillo en el suelo de un bosque tropical caducifolio y uno subcaducifolio en Chamela, Jalisco, México. Acta Bot. Mex. 21:1-6.

McGonigle, T.P. 1995. The significance of grazing on fungi in nutrient cycling. Can. J. Bot. 73: S1370-S1376.

McLaughlin, D.J. \& E.G. McLaughlin. 1972. Pure culture studies of fruiting and sporulation in a clavarioid fungus, Pterula sp. Mycologia 64: 599-608. 
McLaughlin, D.J. \& E.G. McLaughlin. 1980. A new species of Pterula (Aphyllophorales) with corticioid characteristics. Can. J. Bot. 58: 1327-1333.

Miyamoto, T. \& T. Igarashi. 2004. Spatial distribution of Collybia pinastris sporophoros in a Picea abies forest floor over a 5-year period. Mycoscience 45: 24-29.

Moore, D. 1998. Fungal Morphogenesis. Cambridge University, Cambridge, England.

Moore, D., A.C. Gange, E.G. Gange \& L. Boddy. 2008. Fruit bodies: their production and development in relation to environment, p. 79-103. In L. Boddy, J.C. Frankland \& P.V. West (eds.). Ecology of Saprotrophic Basidiomycetes. Academic, London, England.

Moore, D., G.D. Robson \& A.P.J. Trinci. 2011. $21^{\text {st }}$ Century Guidebook to Fungi. Cambridge University, Cambridge, England.

Moore-Landecker, E. 1996. Fundamentals of the Fungi. Prentice Hall, Upper Saddle River, New Jersey, USA.

Morimoto, N. \& Y. Oda. 1973. Effects of light on fruit-body formation in a basidiomycete, Coprinus macrorhizus. Plant Cell Physiol. 14: 217-225.

Mswaka, A.Y. \& N. Magan. 1999. Temperature and water potential relations of tropical Trametes and other wood-decay fungi from the indigenous forests of Zimbabwe. Mycol. Res. 103: 1309-1317.

Munguia, P., G. Guzmán \& F. Ramírez-Guillén. 2006. Seasonal community structure of macromycetes in Veracruz, Mexico. Ecography 29: 57-65.

Palacio-López, K. \& N. Rodríguez-López. 2007. Plasticidad fenotípica en Lippia alba (Verbenaceae) en respuesta a la disponibilidad hídrica en dos ambientes lumínicos. Acta Biol. Colomb. 12: 187-198.

Peabody, D.C., R.B. Peabody, M.G. Tyrrell, M.J. Towle \& E.M. Johnson. 2003. Phenotypic plasticity and evolutionary potencial in somatic cells of Armillaria gallica. Mycol. Res. 107: 408-412.

Pilz, D., R. Mclain, S. Alexander, L. Villarreal-Ruiz, S. Berch, T.L. Wurtz, C.G. Parks, E. McFarlane, R. Molina \& J.E. Smith. 2007. Ecology and management of morels harvested from the Forests of Western North America. Department of Agriculture, Forest Service, Pacific Northwest Research Station, USA.

Salerni, E., A. Laganá, C. Perini, S. Loppi \& V. De Dominicis. 2002. Effects of temperature and rainfall on fruiting of macrofungi in oak forests of the Mediterranean area. Isr. J. Plant Sci. 50: 189-198.

Sánchez-Jácome, M.R. \& L. Guzmán-Dávalos. 1997. Nuevos registros de Thelephora (Aphyllophorales, Basidiomycotina) para México. Rev. Mex. Mic. 13: 70-77.

Schmidt, O. 2006. Wood and tree fungi: biology, damage, protection, and use. Springer, Berlin, Germany.

Singh, S.K., S. Kamal, M. Tiwari, R.D. Rai \& R.C. Upadhyay. 2004. Myco-ecological studies of natural morel bearing sites in Svalik Hills of Himachal Pradesh, India. Micol. Apl. Int. 16: 1-6.

Solís, V.E. 1993. Características físicoquímicas de un suelo en un ecosistema tropical estacional. Tesis de Licenciatura, Universidad Nacional Autónoma de México, D.F., México.

Stalpers, J.A. 1993. The Aphyllophoraceous Fungi I. Keys to the species of the Thelephorales. Stud. Mycol. 35: $1-168$.

Straatsma, G., F. Ayer \& S. Egli. 2001. Species richness, abundance, and phenology of fungal fruit bodies over 21 years in a Swiss forest plot. Mycol. Res. 105: 515-523.

Suárez-Duque, D. 2004. Diversidad y análisis estructural de los Aphyllophorales del Bosque Protector "Mindo Lindi”, Prov. de Pichincha, Ecuador. Lyona 7: 83-89.

Valladares, F., E. Gianoli \& J.M. Gómez. 2007. Ecological limits to plant phenotypic plasticity. New Phytologist 176: 749-763.

Watling, R. 1996. Patterns in fungal development-fruiting patterns in nature, p. 182-222. In S.W. Chiu \& D. Moore (eds.). Patterns in fungal development. Cambridge University, Cambridge, England. 